
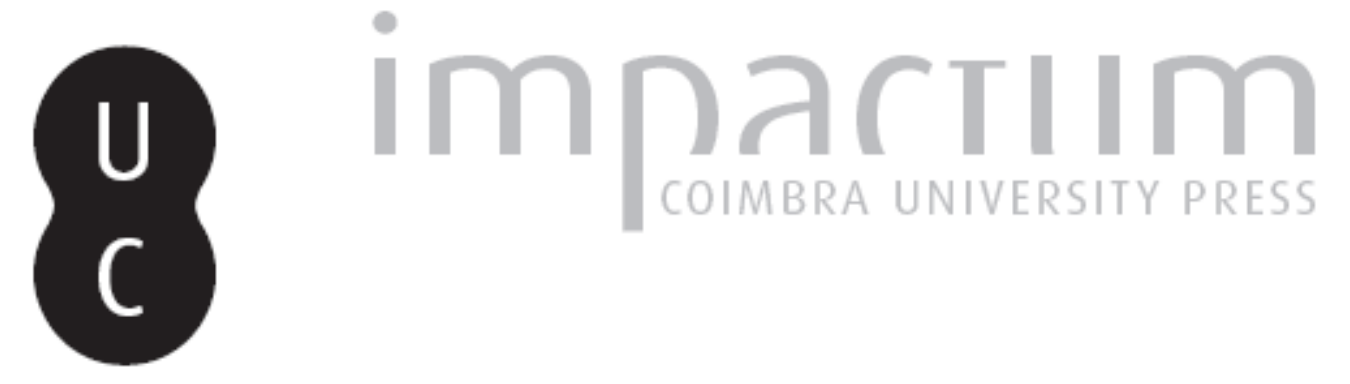

\title{
Competition in Context: philonikia in Agesilaus-Pompey
}

Autor(es): $\quad$ Trego, Kristine M.

Publicado por: International Plutarch Society

URL persistente:

URI:http://hdl.handle.net/10316.2/36352

DOI:

DOI:http://dx.doi.org/10.14195/0258-655X_10_4

Accessed : $\quad$ 26-Apr-2023 09:38:25

A navegação consulta e descarregamento dos títulos inseridos nas Bibliotecas Digitais UC Digitalis, UC Pombalina e UC Impactum, pressupõem a aceitação plena e sem reservas dos Termos e Condições de Uso destas Bibliotecas Digitais, disponíveis em https://digitalis.uc.pt/pt-pt/termos.

Conforme exposto nos referidos Termos e Condições de Uso, o descarregamento de títulos de acesso restrito requer uma licença válida de autorização devendo o utilizador aceder ao(s) documento(s) a partir de um endereço de IP da instituição detentora da supramencionada licença.

Ao utilizador é apenas permitido o descarregamento para uso pessoal, pelo que o emprego do(s) título(s) descarregado(s) para outro fim, designadamente comercial, carece de autorização do respetivo autor ou editor da obra.

Na medida em que todas as obras da UC Digitalis se encontram protegidas pelo Código do Direito de Autor e Direitos Conexos e demais legislação aplicável, toda a cópia, parcial ou total, deste documento, nos casos em que é legalmente admitida, deverá conter ou fazer-se acompanhar por este aviso.

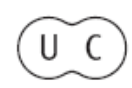




\section{Ploutarchos, n.s.}

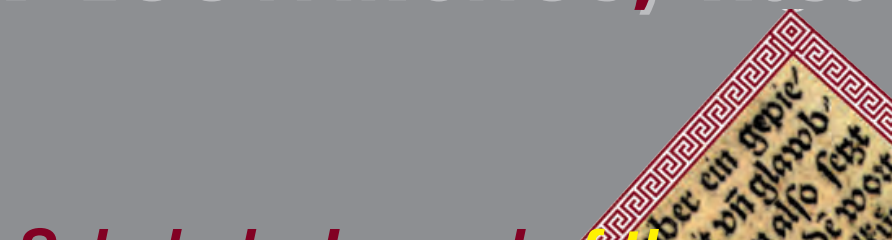

Scholarly Journal or (5) $x, 30$

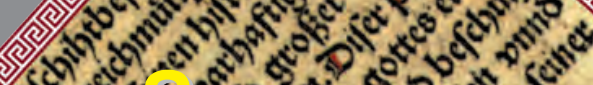

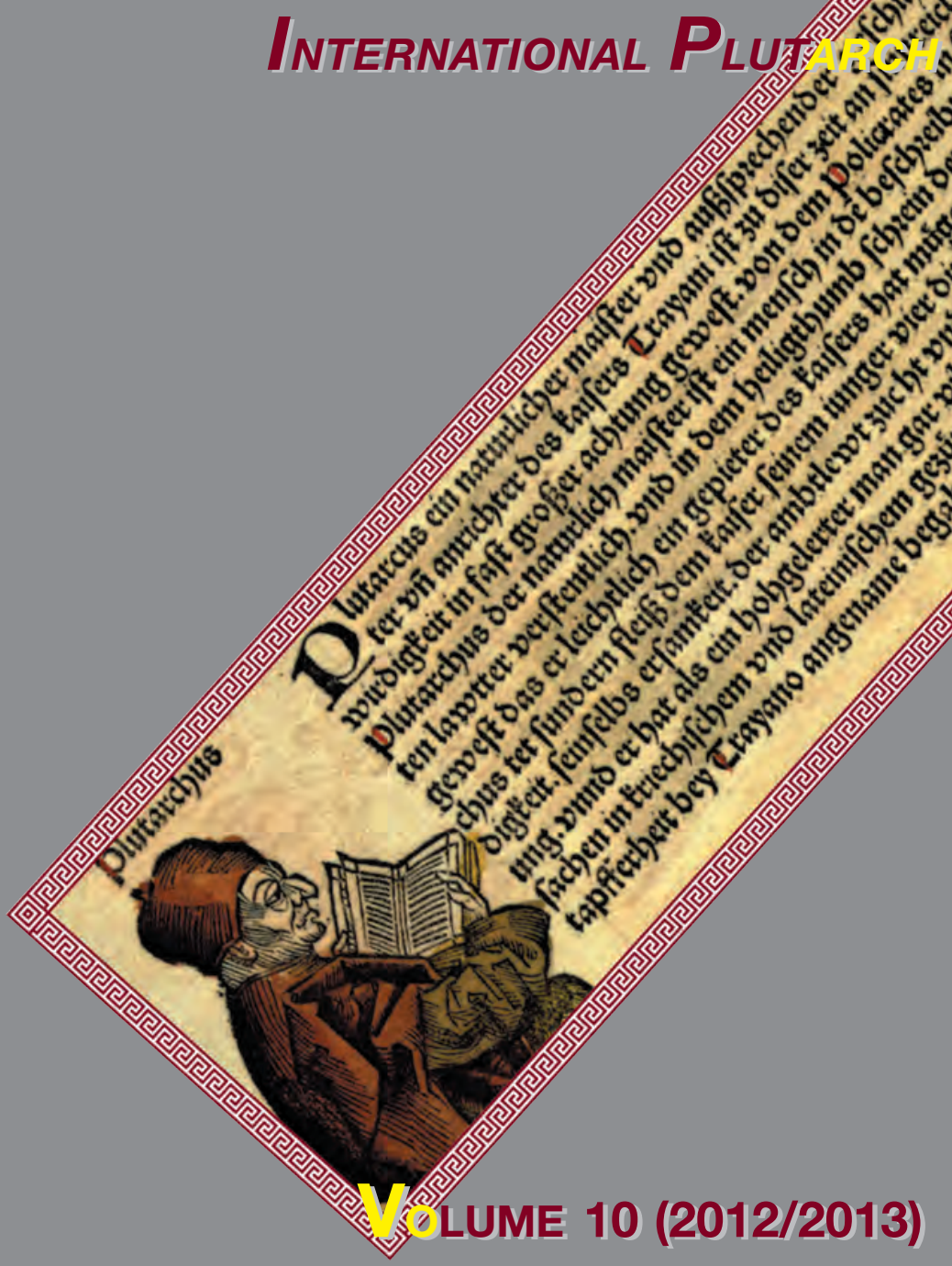

University of Málaga (Spain) Utah State University, Logan, Utah (U.S.A.) 


\title{
Competition in Context philonikia in Agesilaus-Pompey by \\ Kristine M. Trego \\ Bucknell University \\ kris.trego@bucknell.edu
}

\begin{abstract}
In the Lives of Agesilaus and Pompey, Plutarch explores the role of competition in government and demonstrates that the absence or excess of philonikia is detrimental to a state. This balanced treatment of competition's role in government contrasts with Plutarch's negative presentation of philonikia in the Moralia, wherein Plutarch is commenting on contemporary society. This paper explores the possible influence that Plutarch's exposure to contemporary politics had on his presentation of the role of political competition in Agesilaus-Pompey.
\end{abstract}

Key-Words: Plutarch, Philonikia, Praecepta gerendae reipublicae

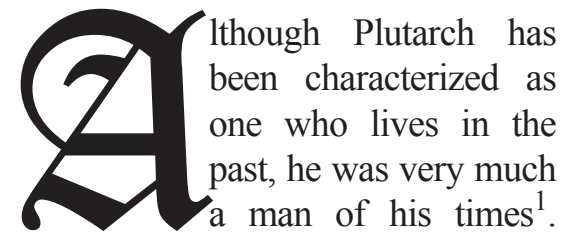

He looked to history for inspiration, but his writings were not intended for those seeking to decipher the past. He wrote for his contemporaries, some of who were engaged in or aspiring towards a life in politics. Plutarch was a connected man, who was well travelled from an early age, and intimate with the political elite and a member of embassies ${ }^{2}$. He

1 As quite bluntly stated by R. H. BARROw, 1967, 146: "Plutarch lived in the past. His mind ranges freely over Greek mythology, religion, literature, and history. If he reflects upon these, he reflects upon people and motives, rather than upon movement and development of ideas and thoughts."

2 See C. P. JONES, 1971, 13-19 for a detailed reconstruction of Plutarch's activities during his youth. Plutarch mentions his trip to Egypt at Quaest. conviv. 678 C, travelling to Delphi with Ammonius during Nero's visit at de E Delphico 385 B, and Smyrna's litigations before the proconsul at anim. an corp. aff. 501E-F. Plutarch mentions his participation in a delegation sent to the proconsul of Achaea at Praec. ger. reip. 816C.

PloutarChos, n.s., 10 (2012/2013) 63-74

ISSN 0258-655X 
spent time in Rome, and was sufficiently versed in politics that the politically aspirant sought him out for advice ${ }^{3}$. He counted among his friends many politically active and connected Romans, including the dedicatee of the Lives, Q. Sosius Senecio, a friend of Trajan ${ }^{4}$. Yet other than the stray comment, Plutarch rarely commented directly on the political events of his lifetime in his Lives. That is not to say, however, that his experiences with the political vicissitudes of Rome and the Greek poleis are absent from his biographical portraits, and in fact they color his presentation of the past. One example of how his involvement with politics may have affected his treatment of history in the Lives is his perception of the role that rivalry and competition, philonikia, played in the politics of history ${ }^{5}$.

The penchant for competition, philonikia, is a frequent character trait that Plutarch explores in several of his Lives. Neither wholly good nor wholly evil, Plutarch dissects the effects of rivalry upon individuals, politics, and states. In the Lives of Lycurgus, Numa, Phocion, Cato Minor, Lysander, Sulla, Philopoemen, and Flamininus the term or a variation of it appears one to three times $^{6}$. There is, however, one pair of
3

4

5

6

Demosth. 2.2; Praec. ger. reip. 805A; C. P. Jones, 1971, $20-27$.

Thes. 1.1; Demosth. 1.1; Brut. 1.1.; quaest. conviv. 612E.

P. A. STADTER, 2011, 238-241 clears muddy waters that surround the spelling of philonikia, which often appears as philoneikia in some editions of Lives and Moralia, and cites the etymological argument that the noun would be philoneikeia if derived directly from neikos. While neikos is the noun that Plutarch uses in Agesilaus 5 alongside philonikia, and thus clearly links the two, Stadter shows that from its earliest appearance in writing philonikia was often used in a negative sense denoting hostile competition. The proximity of the two terms in Agesilaus 5 suggests that Plutarch also has this negative aspect of philonikia in mind. See also P. A. Stadter, 2011, no. 41. C. Pelling, 2002, 345 and no. 24, also tackles the question of the word's spelling and whether Plutarch's audience would associate philonikia with nikê or neikos, but argues that both associations would likely be felt. He finds it unlikely that philonikia and philoneikia were separate words, and rather that authors, including Plutarch, were indifferent to the spelling. He, too, argues, however, that philonikia clearly had separate connotations depending on the context of its use and also looks to words that are clustered with it within a passage to decipher a stronger association with nikê or neikos within a particular passage.

Lycurg. 2.2; 13.5; 16.5; Num.3.2, 8.10; 17.1; Phoc. 10.6; Cato Min. 51.3; Sull. 15.3. Phil. 3.1, 17.7, 18.3; Flam. 11.6, 13.2. The Philopoemen-Flamininus pair warrants attention and particularly Flam. 11.5-6. In this passage, not only is Agesilaus cited as a flawed leader who, although successful militarily, could not transform his victories into lasting success, but also that this failure was into due, in part, to his philonikia. Moreover, such contentious leaders bear responsibility, Plutarch asserts, for Greece's servitude to Hellenistic kings and Rome successively. For more on the Phil.-Flam. pair, see S. SwaIn, 1988, 335-347 and esp. 341, 343-344. 
Lives, the Agesilaus-Pompey, where it takes center stage, appearing eleven times in Agesilaus and five times in Pompey ${ }^{7}$. It is significant that in the paired Lives where Plutarch most frequently uses the term, the subjects were men who were involved in and contributed to the breakdown of their states. In the fourth century BCE, under Agesilaus' long rule, Sparta slid from its pinnacle of power after the defeat of Athens to its degradation at the hands of Thebes. Similarly, the Roman Republic crumbled during the first century $\mathrm{BCE}$ and collapsed under the weight of civil war between Caesar and Pompey, which ushered an entirely new political system into Rome. It is no coincidence, therefore, that Plutarch chose philonikia to be one of the themes of character that would bind these two men, their fortunes, and their times together.

My primary focus will be upon three passages in this pair in which Plutarch directly comments on the necessary role and concurrent risks of philonikia in politics: Agesilaus 5.5-7, Pompey 47.4 and 70.1. These passages, and especially Agesilaus 5.5-7, lay groundwork for the interpretation of the pair, but also give insight into Plutarch's distaste for factional contention in contemporary politics. Hillman has demonstrated the importance of philonikia in the interpretation of the pair of Lives. He shows that the argument that Plutarch begins in Agesilaus 5 is completed by Pompey 70, and connects the narrative of the two halves of the pair. Where his concern was to demonstrate the importance of Plutarch's authorial statements to reading this pair, I suggest that Plutarch uses these historical subjects to explore the role and risks of competition in politics.

Plutarch's distaste for philonikia is even more palpable in the Moralia and especially in Praecepta gerendae reipublicae. There he warns against the dangers that excessive rivalry brings upon civic politics and cautions that philonikia threatens to enervate the Greek cities further by inviting Roman intervention. The threats inherent in political competition were as real in Plutarch's day as they were in Agesilaus or Pompey's. Plutarch's life spanned a tumultuous period of civil war in 69 , the autocracy of Domitian and vacillations of power that followed ${ }^{8}$. Closer to his

7

Ages. 2.2, 4.4, 5.5, 5.7, 7.4, 11.6, 18.4, 23.11, 26.6, 33.2, 34.2; Pomp. 14.3; 31.2; 35.2; $67.9 ; 70.1$.

8

Many of Plutarch friends were participants in the turbulence of 69, while others rose to prominence under Domitian; see C. P. Jones, 1971, 50-51. The impact of these relationships on Plutarch cannot be ignored. They would have given him insight into periods of uncertainty and colored his vision of history and the vicissitudes of government, including civil war. While civil war did not erupt after the assassination of Domitian, it threatened to do so during the tenure of Nerva. See A. BERriman \& M. TodD, 2001, 312331; J. D. Grainger, 2003. 
heart, however, were the perils that internal competition in the Greek cities brought and which Plutarch condemned.

How did the context of Plutarch's experiences and involvement in the political circles of Greece and Italy shape the advice he gave in the Praecepta gerendae reipublicae? Moreover, how did it affect his characterization and perception of the past? This paper will attempt to address these questions by looking at how Plutarch warns against philonikia in the Praecepta gerendae reipublicae and incorporates competition into Agesilaus-Pompey. Stadter has recently examined Plutarch's use of philonikia in his corpus and finds that Plutarch often stressed the negative quality of the term, particularly when commenting upon his contemporary society. I want to continue the discussion by asking whether Plutarch's presentation of philonikia in Agesilaus-Pompey can also be read as a commentary on rivalry and factionalism in local and imperial politics during his lifetime.

The Greek cities, which were always under Roman rule during Plutarch's lifetime, were hardly in a state of continual calm and mutual cooperation. The contention that had been an element of the often hostile interactions between Greek cities for centuries had continued to typify civic politics after Rome's intervention into Greek affairs. It was civic factionalism and the resultant stasis, which erupted among the Greek cities after Nero's proclamation of Greek freedom, that led to Vespasian's reintroduction of direct rule ${ }^{9}$. Continued competition between the Greek cities and factionalism within civic politics contributed to Rome's further intervention into Greek affairs, which resulted in the enervation of civic autonomy that both Plutarch and his contemporary, Dio of Prusa, lamented ${ }^{10}$. It is clear that competition was hardly absent from civic politics and its persistence must have shaped Plutarch's opinions about philonikia. Indeed, in a recent study Stadter investigates Plutarch's views of philonikia and his warnings against unchecked rivalry among politicians and shows that Plutarch's treatment of philonikia is almost wholly negative in the Moralia, while his assessment of competition in the Lives is less direct ${ }^{11}$.

9 Pausanius (7.17.3-4) attributes the resultant stasis to the generals of Achaea and holds them responsible for Vespasian's reintroduction of tribute payment and Roman rule. See also S. SwAIN, 1996, 228-340 and no. 39. Cf. Philostratus, Life of Apollonius 5.41 which also mentions Vespasian's charge of stasis as the reason for his reversal of Nero's proclamation.

Praec. ger. reip. 813F. See S. SwAIN, 1996, 216-225 for discussion of Dio's orations to the Tarsians, Niceans, and Nicomedians where he urges concord among the cities.

11 P. A. StAdTER, 2011, 244-246. 
In De fraterno amore, Plutarch warns against rivalry as a threat that tears apart families and drives one brother to steal from the other as if from an enemy ${ }^{12}$. In his political essay, An seni respublica gerenda sit, Plutarch describes it as a disease that breeds envy and encourages older men to participate in politics because they are free from this trait that is more profitable for younger men ${ }^{13}$.

Most germane to the present discussion are Plutarch's warnings against philonikia in the Praecepta gerendae reipublicae where variations of the term appear nine times ${ }^{14}$. In this political essay, he urges the young Menemachus of Sardis to work in harmony with other aristocrats and not be too confrontational as he gets into politics. He warns against philonikia as a motive for entering politics, and urges any aspiring statesman to attempt to expel it from his soul ${ }^{15}$. Plutarch reminds Menemachus that the Greek cities are no longer autonomous, but their magistrates now must beware the
Roman boots above their heads ${ }^{16}$. He condemns those citizens who invite the Romans to settle their public disputes, which erodes the authority of the city's assembly and senate ${ }^{17}$. Such excessive competition among leading citizens not only throws the city into unrest, but also humiliates the city by necessitating the involvement of Rome and injects bitterness into disputes ${ }^{18}$.

Plutarch was certainly not the first to depict philonikia negatively or link it with political turmoil. Stadter traces the depiction of philonikia as potentially damaging back to Simonides and Pindar and, in a political context, to Thucydides and Aristotle, who, like Plutarch, directly link it to contention and civil unrest ${ }^{19}$. Nonetheless, Plutarch's connection between philonikia and civil strife is not simply a continuity of feeling that goes back to Classical historians. Plutarch witnessed the consequences of rivalry and factionalism both in the Greek

12 483E; see also 481A, 483A, 487F, 488A-B.

13 788E, 794A, 795A.

14 798C, 807A, 811D, 815A, 815B, 819B, 819C, 825A, 825E.

15 P. A. STADTER, 2011, 245; Praec. ger. reip. 798C, 807A.

16 Praec. ger. reip. 813D-F, 815A-B. Similarly, Dio of Prusa bemoaned the weakness of the Greek cities while still recognizing they retained some autonomy under Roman rule although he, too, warned against internal disputes in his speech to the Nicomedians (Or. 38). For a thorough discussion of Dio's attitudes towards Roman rule and the politics of the cities, see S. SwAIN, 1996, 187-241, and esp. 206-225.

17 815A.

18 Praec. ger. reip. 815B, 825A, 825E; cf. An seni 787C.

19 P.A. STADTER, 2011, 241-243

PloutarChos, n.s., $10(2012 / 2013)$ 63-74

ISSN 0258-655X 
cities and among Romans. Likewise, he witnessed that the suppression of opposition could foster an autocracy like that of Domitian's reign. To Plutarch, the threats of philonikia were not only historical or hypothetical, but touched the world in which he lived. Contemporary political circumstances evidently affected Plutarch's political advice in the Moralia, but did it also shape his presentation of history in the Lives? Certainly there is a connection between his warnings against philonikia in the Moralia and his more complex view of it in Agesilaus-Pompey. And so let us turn now to the passages from those Lives.

Plutarch describes Agesilaus as overly competitive from his earliest days of youth (2.2) and this trait reappears throughout the biographical portrait. It is philonikia that spurs Agesilaus to envy Lysander's reputation in Asia Minor and results in Agesilaus' humiliation of and break with his childhood friend $(7.4)^{20}$. At four points in the story, Plutarch attributes philonikia as the impetus behind Agesilaus' relentless hostility towards Thebes ${ }^{21}$. At 18.4 Agesilaus is carried away by philonikia during a battle against the Thebans, which costs the Spartans victory and nearly results in Agesilaus' death. Philonikia spurs Agesilaus to support Phoebidas' seizure of the Cadmeia (23.11) and wins him resentment from the Spartan allies who grew weary of battling Thebes to gratify Agesilaus' obsession (26.6). Most significantly, Plutarch links the king's philonikia directly to Sparta's decline after the Theban invasion of Laconia and liberation of Messene (34.2). Only once does Plutarch portray Agesilaus' philonikia in a positive light and this is when the king uses it to curb his desire for Megabates (11.6) ${ }^{22}$. At all other points in the Agesilaus, Plutarch assesses the king's competitiveness as negatively as he does in the Moralia and yet argues that neikos itself is a key component of a functional universe and government. If Plutarch predominately portrays philonikia as a negative influence and impetus in Agesilaus' Life, how does his argument in chapter 5 for the necessity of neikos in the universe and competition in the Spartan government fit into this viewpoint? Part of the answer may be that Agesilaus' rivalry was against Thebes rather than individuals within the Spartan political system. In chapter 5, Plutarch argues that competition within a government is necessary to prevent an individual's power from going unchecked. Plutarch reveals that Agesilaus removed opposition against him within the state and this gave the king unrivaled power that proved detrimental to Sparta's hegemony. In 5.5-7, Plutarch

20 This echoes An seni 788E where Plutarch describes philonikia as a sickness that breeds envy. 21 Ages. 18.4, 23.11, 26.6, and 34.2.

22 On this passage, see J. BENEKER, 2012, 211-214. 
makes the argument that the absence of any competition against Agesilaus' power by his co-king or the ephors and gerontes was contradictory both to the Spartan constitution and the laws of the universe.

\section{5-7}

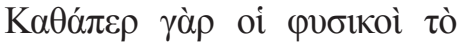

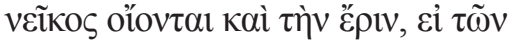

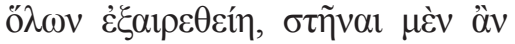

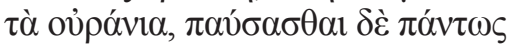

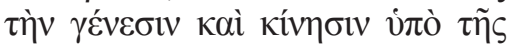

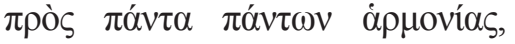

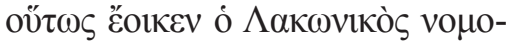

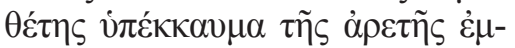

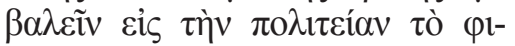

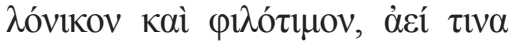

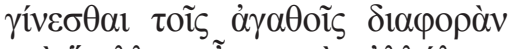

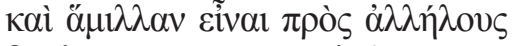

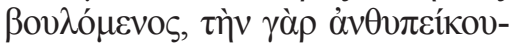

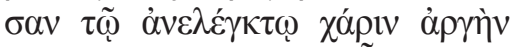

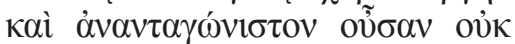

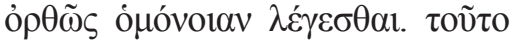

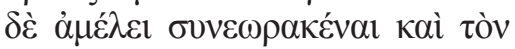

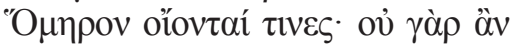

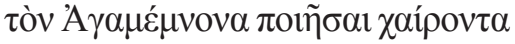

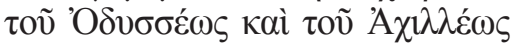

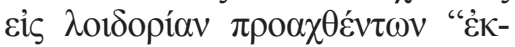

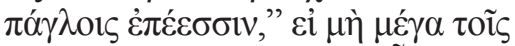

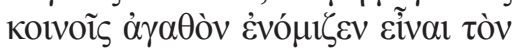

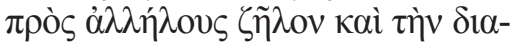

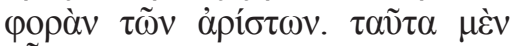

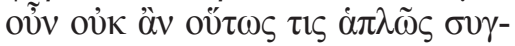

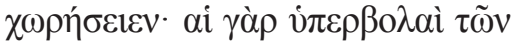

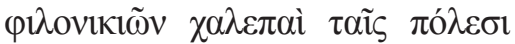

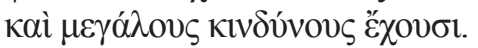

The natural philosophers maintain that if contention and strife were expelled from the universe, then the heavens would stand still and all genesis and movement would cease in consequence of the general harmony. And so the Spartan Lawgiver seems to have introduced rivalry and ambition into his civil polity as the fodder for excellence, desiring that good citizens should always be somewhat at variance and in conflict with one another, and thinking that complaisance which weakly yields without debate, which knows no effort and no struggle, is wrongly labeled concord. And this is the view that some think even Homer doubtlessly held; for he would not have made Agamemnon enjoy Odysseus and Achilles being carried away in the abuse of each other with "vehement words," if he did had not thought the general interests likely to profit by the mutual rivalry and quarrelling of the leading men. And yet this principle must not be accepted without some reservations, for excessive competition is a burden for cities and brings great dangers.

In this passage, Plutarch pauses from his narrative on Agesilaus' life to explore the concept of universal harmony as composed of equal parts of competition and cooperation, and he relates this philosophy to the balance of power within the Spartan constitution between the two kings, members of the Gerousia, and ephors ${ }^{23}$. At 4.2 Plutarch to signify Lycurgus, in his life on the man he notes that it was not until 130 years 
references Xenophon's statement that Agesilaus achieved unrivaled power to the point that he could do as he pleased by acting obediently to the state, and then illustrates how this obedience was a guise for dispelling all opposition ${ }^{24}$. Greatest power in the Spartan state was intended for the ephors and members of the Gerousia, who were expected to restrain the power of the kings, and this created a healthy tension between the branches of government (4.3-4). Agesilaus, however, subverted the traditional structure by winning over the ephors and gerontes with acts of kindness and gifts and thereby increased his own power (4.5-6).

It was the excess of cooperation between these branches of powers that resulted in an imbalance that ultimately contributed to Sparta's downward spiral. In the opening chapters of this Life, Plutarch has established Agesilaus as philanthropos and philonikos. He ends the first section (chapters 1-5) with a foreshadowing of where he will be leading the story and the principles that will govern the subject's actions. Agesilaus will lead Sparta towards its nadir by creating a false harmony within the government of the city (4.4), which stemmed from his philanthropia and resulted in complacency, and by his excessive ambition (philotimia) focused upon the destruction of Thebes $(23.6)^{25}$. At 5.5-7, Plutarch argues that just as the universe would cease to function without equilibrium between strife and concord, so too would the Spartan government cease to operate effectively without opposition and competition between the leading men of the state. This, Plutarch maintains, was the brilliance of the Spartan mixed constitution and the reason for the state's ascendancy at the time that Agesilaus came to the throne ${ }^{26}$. Therefore, when Agesilaus removed competition with the ephors and gerontes from the political equation, he created an imbalance that would spell ruin for Sparta. It was not only the ephors and gerontes who were supposed to bridle the king's power, however, but also the king's royal colleague. Agesilaus removes this check against his authority as well when he wins over his younger co-king Agesipolis (20.7-9). Agesilaus' ability to turn enemies into friends and thereby erase all opposition against

after Lycurgus that the first ephors were created by king Theopompus, Lycurg. 7.1-2. Theopompus' objective was, however, the same: that institutionalized rivalry between the branches of government would give longevity to the state.

Xen. Ages. 6.4.

25 P.A. Stadter, 2011, 242 notes that Thucydides also connected philonikia with the philotimia of factions in his analysis of the origins of stasis (3.82.8). All Greek texts are from the edition of K. Ziegler; English translations are adapted from B. Perrin.

26 Lyc. 7.1-2; Ages. 4.4. 
his power creates nothing less than an autocracy. The warning is clear: neikos and eris are as necessary for safeguarding the cosmos as philonikia is for guarding against autocracy in a state.

As if to validate the parallelism he draws between a harmonious universe and harmonious Spartan polity, Plutarch cites a Homeric model ${ }^{27}$. Indeed, the rivalry between Odysseus and Achilles and the delight that Agamemnon takes therein echoes the balance between the dual kingship and the ephors in the Spartan constitution. And yet, harmony is created by a tension between equal parts of competition and cooperation, and Plutarch is careful to remind his reader of the dangers of unrestrained rivalry. The caveat against excessive competition comes at the close of the chapter: philonikia that is allowed to run unchecked burdens a city and results in great danger for the state. Plutarch goes no further with the argument at this point and, unlike his appraisal on the need for competition between leading men as evidenced by the Homeric heroes, he provides no example or parallel to illustrate the consequences of excessive philonikia.

The counterpart to this argument lay in the second half of the pair. The excess of political complacency in the Life of Agesilaus is answered by the excess of competition in the Life of Pompey.
Taken together the pair demonstrates Plutarch's conviction that neikos and eris are necessary elements of harmony, both in the universe and in a political state. Where the excess of cooperation of Agesilaus with the ephors, gerontes, and co-king disrupted political balance in fourth century Sparta, the excess of competition between the leading men of Rome, and particularly between Pompey and Caesar, resulted in the ultimate destruction of the Republic. At the end of the section from Agesilaus 5, Plutarch warned that, "one ought not absolutely yield and assent to these things; for excessive rivalry is a burden for cities and brings great dangers." The reader must hold this warning in mind and await the rest of the argument. It comes at last in second half of the pair, and specifically in chapters 47 and 70 of Pompey.

47.4

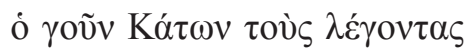

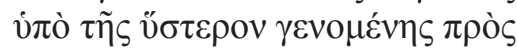

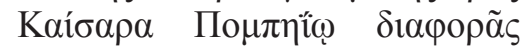

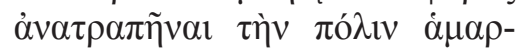

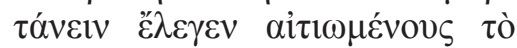

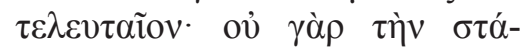

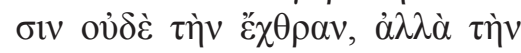

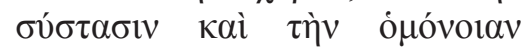
$\alpha$

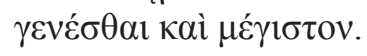

At any rate, Cato, when men said that the city had been overturned by

27 D. R. Shipley, 1997, 112: "The use of Homeric quotation (Od. 8. 77-78) in support of an argument is a rhetorical technique, and demonstrates cultural continuity with the past in Plutarch's thinking." 
the quarrel that later occurred between Caesar and Pompey, declared that they were wrong to lay the blame on the thing that simply happened last; for it was not their discord nor even hatred, but their alliance and harmony that brought the first and greatest evil upon the city.

Here, Cato echoes Plutarch's sentiments in Ages. 5. The alliance between Caesar and Pompey and the temporary cessation of their mutual competition created a false and dangerous harmony. This harmony was the beginning of the Republic's ruin since together they subvert political opposition and their forged alliance set in place the conditions for the inevitable civil war. After the rival men's ambitions and self-interests could no longer be held in check and the last thin thread that tied the men together broke with the death of Julia, the false harmony was overwhelmed by the rivalry between Caesar and Pompey. With the battle at Pharsalus, Plutarch can round off his argument with a concrete example of the dangers which excessive competition brings upon a state.

\section{1}

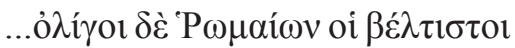

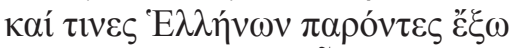

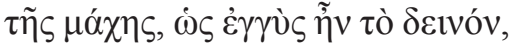

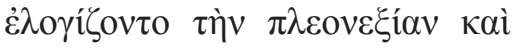

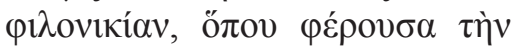

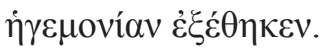

But a few best of the Romans and some of the Greeks, who were present without taking part in the battle, now that the dreadful crisis was imminent, began to reflect upon the pass to which greed and eager rivalry had brought the sovereign Roman state.

At last we see the "great dangers" that excessive rivalry can bring upon a state that Plutarch warned against in Agesilaus 5. Unrestrained philonikia results in stasis. Taken with Agesilaus 5 and Pompey 47, these statements bind together the lives and history of these two men and their states ${ }^{28}$. In addition to contributing to the narrative cohesion to the two halves of the pair, however, these passages advise the astute reader as to the nature of competition in politics more generally. His warnings against the absence or excess of rivalry not only transcend the boundaries of the physical world, but also the boundaries of time. Excess competition as well as its absence brings risks to a city like fourth-century BCE Sparta and to an empire like Rome, and this warning echoes Plutarch's advice to his contemporaries in the Moralia.

Furthermore, Plutarch continues this passage with a lamentation on how the state was plunged into civil war, pitting brother against brother, because of unchecked passions (70.2-7). Rather than enjoy the empire already won or

As shown by T. P. Hillman, 1994, esp. 265-275. 
turn their army against unconquered barbarians, Caesar and Pompey unleashed their armies against one another. The alliance they once forged through the marriage of Julia to Pompey was now exposed as an empty partnership ${ }^{29}$. This is similar to the sentiments expressed in Agesilaus 15.3-4 wherein Plutarch laments that if the Greek poleis would only have set aside their quarreling, they could have joined their forces against Persia and preemptively thwarted the rise of Macedonia. This was a task that Agesilaus had come close to achieving, but had to abandon on the request of the ephors, who recalled him in order to deal with hostilities at home. Competitionthis time between cities - enervated the Greek cities, and set the poleis on a track towards subjugation by Macedonia, and eventually Rome, due to their factionalism and unchecked competition ${ }^{30}$. This is the same frustration that Plutarch expresses in the Praecepta gerendae reipublicae; the Greek cities were already under Roman control and internal rivalry and factionalism only increased Roman involvement and further eroded Greek autonomy. Moreover, factionalism brought real risks in his day both to those at odds in the cities and among the Roman elite. When Rome intervened into the internal feuds at Sardis, they put Pardalas to death. Likewise, those opposed to the emperor were exiled or executed, including Plutarch's associates Arulenus Rusticus and Avidius Nigrius. Plutarch's disdain for factionalism in the politics of his day colors his presentation of the negative effects of philonikia in Agesilaus' Sparta and the Rome of Pompey's day.

Plutarch's view of competition is more nuanced in the Lives than in the Praecepta gerendae reipublicae, but he stresses the need for the moderation of political rivalry ${ }^{31}$. Agesilaus-Pompey is a clear example of the risks that are inherent in the absence or excess of competition at the highest levels of government. In his conclusions, Stadter touches on Plutarch's contemporary political environment and the tumult in Rome that resulted in civil war and

29 Pomp. 70.3-7.

30 Along a similar vein, P.A. STADTER, 2011, 253 has shown that philonikia in PhilopoemenFlamininus is dishonorable when it results in quarreling among the Greek cities, but honorable when directed against a foreign power (Rome). See also, SwaIn, 1988, and no. 6 above.

31 P. A. Stadter, 2011, 246-247 suggests Plutarch was aware of both the positive and negative effects of competition, and Lycurgus-Numa demonstrates that dichotomy. Where philonikia is an important part of evaluating the drive of Sparta youths, Numa sought to dispel the competition between Romans and Sabines and foster peace. Likewise, the positive and negative effects of philotimia appear together in the Life of Philopoemen, whose philonikia, coupled with anger and ambition, was destructive, but in the synkrisis with Flamininus, it becomes an honorable part of his fight against Rome on behalf of the Greeks and thus is justifiable; see P. A. StADTER, 2011, 251-253 and no. 49. 
dynasty changes and comments that there need be little wonder that Plutarch had a complex view of philonikia. Indeed, Plutarch was not a man who turned a blind eye to the present and the history that was unfolding around him. For him, philonikia is sometimes dangerous and always risky. Plutarch's experience with autocrats like Domitian, who removed his opposition, may have fostered the emphasis on philonikia in Agesilaus' story. In Plutarch's presentation of history, Agesilaus dampened the opposition from ephors and his coking by winning them over, and this resulted in Agesilaus' supremacy in Spartan politics, if not a full autocracy. Conversely, the threats of excessive rivalry were woven into Pompey and shown to result in deplorable stasis and a civil war that set brother against brother. That Plutarch never comes out directly against autocracy or competition may indicate that he has not found a suitable answer to his question of how much neikos is needed for political harmony. The closest answer we get is in Agesilaus 5: either too little or too much philonikia will destroy a state. And to anyone thinking of a life in politics, he offers the advice to tread carefully the tightrope between the two lest you bring destruction to yourself or your state.

\section{BIBLIOGRAPHY}

BARROW, R. H.,

- Plutarch and His Times, Bloomington, 1967.

BenEKER, J.,

- The Passionate Statesman: Eros and Politics in Plutarch's Lives, Oxford, 2012.

Berriman, A. \& Todd, M.,

- "A Very Roman Coup: The Hidden War of Imperial Succession, AD 96-8," Historia, 50 (2001) 312-331.

GRAINGER, J. D.,

- Nerva and the Roman Succession Crisis of AD 96-99, London, 2003.

HiLLMAN, T. P.,

- "Authorial Statements, Narrative, and Character in Plutarch's AgesilausPompeius," GRBS, 35 (1994) 255-280.

JONES, C. P.,

- Plutarch and Rome, Oxford, 1971.

Pelling, C.,

- "Rhetoric, paideia, and psychology in Plutarch's Lives," in Plutarch and History: Eighteen Studies, Swansea, 2002, pp. 339-347.

SHIPLEY, D. R.,

- Plutarch's Life of Agesilaos: Response to Sources in the Presentation of Character, Oxford, 1997.

STADTER, P. A.,

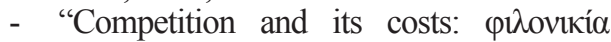
in Plutarch's society and heroes," in G. Roskam \& L. Van Der Stockt (eds.), Virtues for the People: Aspects of Plutarchan Ethics, Leuven, 2011, pp. 237-255.

SwaIN, S.,

- "Philopoemen and Flamininus," ICS, 13 (1988) 335-347.

- Hellenism and Empire, Oxford, 1996. 